\title{
CODE SWITCHING IN BILINGUAL CLASSROOM
}

\author{
Rakhmat Wahyudin Sagala ${ }^{1}$ \\ Universitas Muhammadiyah Sumatera Utara \\ rakhmatwahyudin@umsu.ac.id \\ Dr. Bambang Panca Syahputra, M. Hum ${ }^{2}$ \\ Universitas Muhammadiyah Sumatera Utara \\ Medan, Indonesia
}

\begin{abstract}
Nowadays, universal language which is used in the world is English. The ability of speaking English is being a prerequisite to be someone's success in the future. The aim of this study is to find the phenomenon of code switching in bilingual classroom which focused on types of grammatical code switching and reasons of using grammatical code switching. This research applied descriptive qualitative research which obtained the data from the discourse of lecturers and students in bilingual classroom at Universitas Negeri Medan. The researchers applied observation, interview and documentation. The data showed that lecturers and students used grammatical code switching in the classroom such as 2 tag code switching, 12 inter-sentential code switching, 22 intra-sentential code switching, 3 proper nouns, 1 negative words, 8 similarity of words in languages and 3 discourse marker. There are some reasons why the participants used code switching in their discourse. First, code switching made students more understand what the lecturers explained because not all bilingual students are able to speak English. Second, they used code switching because lack of vocabulary in English and so that they switched languages to make the material were easier to be understood.

Keywords: code switching, types of grammatical code switching, reasons of code switching, bilingual education
\end{abstract}

\section{INTRODUCTION}

The globalization era that occurs in every country in the world makes various educational institutions provide foreign language education including providing bilingual programs. Bilingual means being able to use two languages well. Bilingual learning programs refer to the use of two languages as the language of instruction in the learning process (Anderson and Boyer in Margana, 2009). By applying the bilingual concept, the school and parents expect children to be more proficient and master foreign languages, especially English. In fact, the use of English is not fully used in bilingual classes. Teachers or lecturers and students still use more than one language namely Indonesian and English in the teaching and learning process. This phenomenon can be 
called as code switching. Code switching can occur in societies to make the communication more effective and meaningful. Code switching can be observed mostly in second or foreign language classrooms. It refers to the use of two languages within a sentence or discourse. According to Romaine (2000), code switching is the use of more than one language, variety, or style by a speaker within an utterance or discourse, or between different interlocutors or situations. Istiati in Mutmainah (2008) explains that code switching can occur mainly due to background and topic. Jendra (2010) divides code switching into two classifications namely grammatical code switching and contextual code switching.

This study focuses on grammatical code switching which consists of 7 types such as There are seven types of code switching grammatical namely Tag codeswitching; a bilingual switches short expression in his utterance, Inter-Sentential code switching; a bilingual switches code between sentences, Intra-Sentential code switching; a bilingual switches code within sentences, Proper Noun; a bilingual switches the name of people, places or specific register and noun phrase; a phrase consisted of noun, Negative Words; a bilingual switches non-standard negative words such as "nggak" or "ndak", Languages Similarity; a bilingual switches a word that has same meaning and same sound between languages and Discourse Marker; a bilingual switches discourse marker such as "kok", "kan", "lho", “anu”, etc. According to Malik (1994), there are ten reasons why bilinguals use code switching. They are 1) lack of facility, 2) lack of register competence, 3) semantic significance, 4) to address different audience, 5) to show identity with a group, 6) to emphasize a point, 7) mood of the speaker, 8) habitual expressions, 9) pragmatic reasons and 10) to attract attention. This study focuses on the phenomenon of grammatical code switching which occurs in bilingual classroom. The reality shows that the use of English in bilingual class is not easy to be applied. The lecturers aware that because English is not their mother tongue, so many things cannot be conveyed properly. Consequently, lecturers and students switch their language in teaching learning process. As a result, many schools take bilingual policies with the use of Indonesian language with a larger portion. the study of code switching is considered as an important research to be done because the phenomenon of code switching itself is 
often found in classroom include bilingual classroom. Some researchers have done their research about code switching in the classroom.

Sagala and Rezeki (2018) did a research about the phenomenon of grammatical and contextual code switching in the English Department proposal seminar at STKIP Budidaya Binjai. Grammatical and contextual code switching occurs in the English Department proposal seminar process. D. Moore (2002) in case study code switching and learning in the classroom found code switching analysis in The observation of code switching shows complex learning and communicative strategies, and emphasizes the need to better understand these strategies and their role in the learning process. In ELT classrooms, code switching comes into use either in the teachers' or the students' discourse. Although it is not favored by many educators, one should have at least an understanding of the functions of switching between the native language and the foreign language and its underlying reasons (O. Sert, 2005). The purpose of this study is to analyze grammatical code switching which occurs in biology bilingual classroom at Universitas Negeri Medan. The scopes of this study are to find out types of grammatical code switching used by lecturers and students in bilingual classroom, and reasons why they used grammatical code switching in bilingual classroom.

\section{METHODS}

This research used descriptive qualitative research based on Moleong (2012) who defined qualitative research as a research procedure that produce data in form of words description, written or oral, from people and their behavior that are being observed. Lecturers and students in bilingual classroom at Universitas Negeri Medan became the research subject in this research. The data were taken from discourse of the lecturers and the students during the process of teaching and learning in classroom. In collected the data, researchers used instruments such as observation, interviews, and documentation based on theory of Miles and Huberman (1992). 


\section{Jurnal Serunai Bahasa Inggris \\ Vol.11, No.1, Februari 2019 \\ e-ISSN 2621-010X}

\section{RESULT AND DISCUSSION}

Grammatical Code Switching Analysis

The result of data proved that there were 51 utterances of lecturers and students in bilingual classroom that contain grammatical code switching. Tag code switching consisted of 2 utterances, inter-sentential consisted of 12 utterances, intra-sentential consisted of 22 utterances, proper noun and noun phrase consisted of 3 utterances, negative words consisted of 1 utterances, languages similarity consisted of 8 utterances and discourse marker consisted of 3 utterances.

These are some data examples which were taken from discourse of lecturers and students in bilingual classroom at Universtas Negeri Medan.

1. The example of tag code switching analysis:

Lecturer (man) : Then, you explain by using your own words, ya kan?

The word "ya kan" is kind of tag code switching because the speaker switched short expression from different language in the end of utterance.

2. The example of inter sentential code switching analysis:

Student (woman) : Hari ini kita

pertemuan ke 5. I will teach

you about virus.

From the data, the speakers switched code between sentences. The student used Indonesia and then used English in the second sentence.

3. The example of intra sentential code switching:

Student : virus is sumber penyakit

From the data, the speakers switched code within sentences. The speaker combined

English and Indonesia in one sentence.

4. The example of proper noun/noun phrase

analysis:

Lecturer : "... versi Indonesia"

The word "Indoensia" is a proper noun because it is a name of a country

5. The example of negative words expression:

Lecturer : "Coba gak usah baca" 
The word "gak" is slang word from "tidak" in Indonesia. The word "gak" is a nonstandard negative words.

6. The example of language similarity expression:

Student : "virus akan mati ketika kerada pada 100 derajat celsius lebih."

The speakers used the same meaning and the same writing between English and Indonesia such as "virus" (English) - virus (Indonesia), and "Celsius" (English) selsius (Indonesia)

7. The example of discourse marker expression:

Student : "Ohya, ukurannya microscopic"

The speaker used "ohya" as discourse marker in his utterance.

\section{CONCLUSION}

Based on the result and discussions that have been explained, the researcher concluded that grammatical code switching is often used by lecturers and students in bilingual classroom at Universitas Negeri Medan. Specifically, lecturers and students used seven types of grammatical code switching based on Jendra's theory (2010) namely tag code switching, inter-sentential, intra-sentential, proper noun/noun phrase, negative words, language similarity and discourse markers. They used code switching to make students more understand what the lecturers explained and students have lack of vocabulary in English so that they switched languages to make the material were easier to be understood.

\section{ACKNOWLEDGMENT}

This study supported by APB Universitas Muhammadiyah Sumatera Utara. Beginner Lecturer Research Program Program Penelitian Dosen Pemula Dana APB UMSU Tahun Anggaran 2019.

\section{REFERENCES}

[1] Margana. (2009). Developing Model of Bilingual Education at Vocational High Schools in Yogyakarta. Research Report of Competitive Grant Funded by DIKTI. 
[2] Romaine S. 2000. Language in Society. An Introduction to Sociolinguistics. Second Edition. New York: Oxford University Press.

[3] Mutmainah, Y. 2008. Pemilihan kode dalam Masyarakat Dwibahasa: Kajian Sosiolinguistik Pada Masyarakat Jawa di Kota Bantang Kalimantan Timur. Semarang. Universitas Diponoegoro.

[4] Jendra, Made Iwan Indrawan. 2010. Sociolinguistics: The Study of Societies' Languages. Yogyakarta: Graha Ilmu

[5] Malik, L. 1994. Socio - Linguistics: A Study of Code Switching. Anmol Publication Pvt. Ltd: New Delhi

[6] Sacala R W/ Rezeli T I GO18 Necemher) Grammatical and Contovtual Fado Susitrhino in tho Fnolish Donartmont Pronosal Sominar In Rrd Annual Intornatinnal Cominar on Trancfrrmative Education and Educational Leadership (AISTEEL 2018). Atlantis Press.

[7] D. Moore, "Case Study Code Switching and Learning in the Classroom," International Journal of Bilingual Education and Bilingualism. Vol. 5,No.5,2002, pp. 290-291

[8] O. Sert, "The Function of Code Switching in ELT Classrooms," The Internet TESL Journal. Vol. XI, No. 8, August 2005

[9] Moleong, Lexy J. 2012. Metodologi Penelitian Kualitatif. Bandung: Remaja Rosdakarya

[10] Miles \& Huberman. 1992. Analisis Data Kualitatif. Jakarta: UI-Pre 
Jurnal Serunai Bahasa Inggris

Vol.11, No.1, Februari 2019

e-ISSN 2621-010X 